\title{
Pengaruh Dosis Pupuk Mitra Flora dan Ekstrak Daun Kelor (Moringa oleifera) Terhadap Pertumbuhan dan Hasil Tanaman Sawi (Brassica juncea, L.)
}

\author{
Heriberta Banu ${ }^{\mathrm{a}}$, Roberto I. C. O. Taolin ${ }^{\mathrm{b}}$, Maria Afnita Lelang \\ ${ }^{a}$ Fakultas Pertanian, Universitas Timor, Kefamenanu, TTU - NTT, 85613, Indonesia

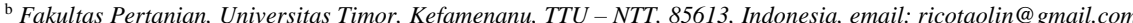 \\ ' Fakultas Pertanian, Universitas Timor, Kefamenanu, TTU - NTT, 85613, Indonesia, email: afnitalelang@ymail.com
}

\section{Article Info}

Article history:

Received 27 Agustus 2015

Received in revised form 1 September 2015

Accepted 29 September 2015

Keywords:

Daun Kelor

Ekstrak

Sawi

\section{Pendahuluan}

Sawi merupakan jenis tanaman sayuran daun yang memiliki nilai ekonomis tinggi. Selain itu, tanaman sawi juga mengandung mineral, vitamin, protein dan kalori (Haryanto et al., 2008). Menurut Nusifera dan Sosiawan (2001) sawi mengandung serat, vitamin A, vitamin B, vitamin B2, vitamin B6, vitamin $\mathrm{C}$, kalium, fosfor, tembaga, magnesium, zat besi dan protein.

Beberapa faktor yang cukup mempengaruhi proses pertumbuhan tanaman adalah persediaan makanan/unsur hara, ketersediaan air, cahaya matahari, suhu udara, oksigen, dan zat pengatur pertumbuhan (ZPT) (Anonim, 1995). Unsur hara yang diperlukan tanaman meliputi unsur hara makro dan mikro. Namun seringkali keberadaan unsur hara dalam tanah belum memenuhi kebutuhan tanaman, sehingga perlu diadakan pemupukan. Dengan pemberian pupuk maka ketersediaan unsur hara bagi tanaman akan bertambah, sehingga pertumbuhan bisa dioptimalkan.

Salah satu pupuk yang bisa diberikan yaitu pupuk cair Mitra Flora karena jenis pupuk ini mengandung berbagai unsur hara yang dibutuhkan tanaman baik unsur hara makro maupun unsur hara mikro. Menurut Lingga dan Marsono (2008), untuk tanaman yang dibudidayakan pada lahan beriklim kering, Mitra Flora akan mampu mengurangi dosis pupuk konvensional yang biasa diberikan melalui tanah. Novizan (2005) menyatakan agar pemupukan dapat berpengaruh secara efektif maka perlu memperhatikan beberapa hal, antara lain pemilihan jenis pupuk, pemakaian dosis/takaran yang sesuai dengan kebutuhan tanaman, dan cara penempatan pupuk.

Selain unsur hara, hasil tanaman juga dipengaruhi oleh zat pengatur pertumbuhan. Menurut Kusumo (1984), zat pengatur pertumbuhan adalah senyawa organik yang dalam jumlah sedikit mendorong, menghambat atau mengatur proses fisiologis di dalam tanaman. Penggunaan zat pengatur pertumbuhan dimaksudkan untuk mempercepat pertumbuhan sekaligus pertumbuhan yang optimum. Tanggapan terhadap zat pengatur pertumbuhan sangat bervariasi tergantung tingkat pertumbuhan yang telah dicapai tanaman dan konsentrasi yang diberikan. Menurut Culver (2012), hormon tanaman dapa digunakan untuk meningkatkan hasil per satuan luas karena mereka mempengaruhi setiap tahap pertumbuhan dan perkembangan tanaman. Prosecus (2006) menyatakan secara umum, ada lima kelompok zat pengatur tumbuh antara lain auksin, giberelin, asam absisat, etilen dan sitokinin. Sitokinin meningkatkan produksi pangan. Zeatin adalah salah satu bentuk dari bentuk yang paling umum terjadi secara alami dari sitokinin pada tanaman.

Daun segar kelor oleifera telah terbukti memiliki kandungan zeatin tinggi. El Awady (2003) cit. Culver (2012) menemukan bahwa Moringa daun dikumpulkan dari berbagai belahan dunia memiliki konsentrasi zeatin tinggi antara 5-200 $\mathrm{mcg} / \mathrm{g}$ daun. Sebelumnya pada tahun 2000, Fuglie menemukan bahwa ekstrak daun kelor yang disemprotkan ke daun bawang, paprika, kacang kedelai, sorgum, kopi, teh, cabai, melon dan jagung dapat meningkatkan hasil tanaman.

Penggunaan zat pengatur tumbuh dengan konsentrasi yang tepat akan meningkatkan hasil, sedangkan pada konsentrasi yang tinggi dapat menghambat pertumbuhan, meracun bahkan mematikan tanaman (Danusastro, 1989). Menurut Weaver (1972) cit Sunu (1999) keberhasilan aplikasi zat pengatur pertumbuhan ditentukan oleh beberapa faktor, diantaranya adalah dosis dan konsentrasi yang digunakan harus tepat, metode pemberian zat pengatur pertumbuhan, waktu pemberian yang tepat, jenis zat pengatur pertumbuhan harus sesuai dengan tujuan pemberian karena golongan zat pengatur pertumbuhan mempunyai spesifikasi sendiri-sendiri terhadap pertumbuhan dan perkembangan tanaman.

Permasalahannya adalah belum diketahui pengaruh dosis pupuk Mitra Flora dan ekstrak daun kelor pada pertumbuhan dan hasil tanaman sawi, untuk itu perlu dilakukan penelitian tentang pengaruh dosis pupuk Mitra Flora dan ektrak daun kelor terhadap pertumbuhan dan hasil tanaman sawi. Penelitian ini bertujuan untuk mengetahui pengaruh pupuk cair Mitra Flora dan ekstrak daun kelor terhadap pertumbuhan dan hasil sawi serta mengetahui dosis pupuk cair Mitra Flora dan ekstrak daun kelor yang tepat bagi pertumbuhan dan hasil sawi.

\section{Metode}

2.1 Waktu dan Tempat

Penelitian dilaksanakan pada bulan Juni sampai Agustus di kebun Fakultas Pertanian, Universitas Timor, Kelurahan Sasi, Kecamatan Kota Kefamenanu, Kabupaten TTU. Topografi berbukit-bukit dengan ketinggian $\pm 400 \mathrm{~m} \mathrm{dpl}$. Curah hujan 900-1.500 mm per tahun, suhu tanah berkisar antara $20{ }^{\circ} \mathrm{C}$ (BPS, 2007)

\subsection{Rancangan Percobaan}

Penelitian ini menggunakan Rancangan Acak Kelompok (RAK) faktorial 3 x 3 yang diulang 3 kali. Faktor pertama adalah dosis pupuk Mitra Flora $(P)$ terdiri dari tiga aras yaitu tanpa pupuk cair Mitra Flora $\left(\mathrm{p}_{0}\right), 60 \mathrm{ml} / \operatorname{tanaman}\left(\mathrm{p}_{1}\right)$, $120 \mathrm{ml} / \operatorname{tanaman}\left(\mathrm{p}_{2}\right)$. Faktor kedua adalah ekstrak daun kelor $(\mathrm{E})$ terdiri dari tiga aras yaitu tanpa ekstrak daun kelor $\left(\mathrm{e}_{0}\right), 75 \mathrm{ml} / \operatorname{tanaman}\left(\mathrm{e}_{1}\right), 150$ $\mathrm{ml} / \operatorname{tanaman}\left(\mathrm{e}_{2}\right)$. Kombinasi perlakuannya adalah $\mathrm{p}_{0} \mathrm{e}_{0}, \mathrm{p}_{0} \mathrm{e}_{1}, \mathrm{p}_{0} \mathrm{e}_{2}, \mathrm{p}_{1} \mathrm{e}_{0}, \mathrm{p}_{1} \mathrm{e}_{1}, \mathrm{p}_{1} \mathrm{e}_{2}$, $\mathrm{p}_{2} \mathrm{e}_{0}, \mathrm{p}_{2} \mathrm{e}_{1}$ dan $\mathrm{p}_{2} \mathrm{e}_{2}$ sehingga terdapat 27 satuan percobaan

2.3 Pelaksanaan Penelitian

a. Persiapan Benih dan Persemaian

Benih yang digunakan dalam penelitian ini adalah benih sawi putih yang di beli di toko sarana produksi pertanian sebanyak satu bungkus seberat $25 \mathrm{~g}$ Benih disemaikan dalam tempat persemaian dengan media kecambah berupa campuran tanah dan pupuk kandang sapi. Sebelum disemaikan media semai disiram menggunakan gembor. Benih kemudian ditabur dalam larikan yang sudah dibuat sebelumnya. Jarak antara larikan $5 \mathrm{~cm}$ dengan kedalaman $2 \mathrm{~cm}$, selanjutnya benih ditutup dengan media tanam. Penyiraman dilakukan pada pagi dan sore hari dengan menggunakan gembor

b. Persiapan Lahan

Lahan dibersihkan dari gulma serta vegetasi lainnya. Lahan yang digunakan berukuran panjang $6,7 \mathrm{~m}$ dan lebar $3,5 \mathrm{~m}$ dengan luas $23,5 \mathrm{~m}^{2}$. Lahan dibagi dalam tiga blok dan pada masing-masing blok dibuat sembilan petak percobaan dengan ukuran panjang $160 \mathrm{~cm}$ dan lebar $20 \mathrm{~cm}$ sehingga secara keseluruhan terdapat 27 petak. Jarak antara petak $15 \mathrm{~cm}$ dan jarak antara blok $40 \mathrm{~cm}$. Blok dan petak ditandai dengan label.

c. Persiapan Media Tanam

Media tanam yang digunakan berupa campuran tanah, arang sekam dan pupuk kandang sapi dengan perbandingan 5:3:4. Media tanam kemudian dimasukan dalam polybag berukuran diameter $20 \mathrm{~cm}$ dan tinggi $20 \mathrm{~cm}$. Polybag kemudian disusun dalam petak percobaan

d. Penanaman

Penyapihan dilakukan setelah bibit berumur 14 hari dengan cara mengangkat tanaman yang sehat dari media semai kemudian ditanam dalam polybag pada sore hari, setiap polybag ditanam satu tanaman sehingga dalam setiap petak percobaan terdapat 5 tanaman dengan jumlah keseluruhan 135 tanaman.

e. Aplikasi Pupuk Cair Mitra Flora

Pupuk cair Mitra Flora diencerkan dengan air dengan perbandingan 1:32 volume dan kemudian disemprotkan langsung ke tanaman. Aplikasi pupuk dilakukan empat kali selama masa pertumbuhan yakni 7 HST, 14 HST, 21 HST dan 28 HST dengan cara penyemprotan menggunakan hand sprayer pada sore hari. Pada sembilan petak percobaan, tanaman tidak diberikan pupuk cair Mitra Flora, pada sembilan petak percobaan diberikan pupuk cair Mitra Flora dengan dosis total $60 \mathrm{ml} /$ tanaman $(10 \mathrm{ml} /$ tanaman pada pemberian pertama, 15 $\mathrm{ml} /$ tanaman pada pemberian kedua dan ketiga serta $20 \mathrm{ml} /$ tanaman pad 
pemberian keempat) dan pada sembilan petak percobaan diberikan pupuk cair Mitra Flora dengan dosis $120 \mathrm{ml} / \operatorname{tanaman}(20 \mathrm{ml} / \mathrm{tanaman}$ pada pemberian pertama, $30 \mathrm{ml} /$ tanaman pada pemberian kedua dan ketiga serta $40 \mathrm{ml} /$ tanaman pada pemberian keempat).

\section{f. Penyiapan dan Aplikasi Ektrak Daun Kelor}

Daun kelor yang digunakan adalah daun kelor muda yang berumur maksimal 35 hari sejak muncul sebagai tunas daun. Daun dihancurkan dengan lesung dengan campuran air 1 liter untuk $1 \mathrm{~kg}$ daun kelor. Bahan yang telah hancur kemudian disaring dengan cara dibungkus kain kemudian diremasremas. Larutan selanjutnya disaring dengan menggunakan kertas filter Whatman No 2. Ekstrak ini digunakan dalam waktu lima jam dari pembuatan, jika belum digunakan, ekstrak atau larutan disimpan dalam kulkas dengan suhu pada maksimal $0{ }^{\circ} \mathrm{C}$ dan hanya diambil bila diperlukan untuk digunakan. Ekstrak diencerkan dengan air dengan perbandingan 1:32 volume dan kemudian disemprotkan langsung ke tanaman. Aplikasi ekstrak daun kelor dilakukan tiga kali selama masa pertumbuhan yakni 10 HST, 17 HST dan 24 HST dengan cara penyemprotan menggunakan hand sprayer pada sore hari. Pada sembilan petak percobaan, tanaman tidak diberikan ektrak daun kelor, pada sembilan petak percobaan diberikan ektrak daun kelor dengan dosis total $75 \mathrm{ml} / \operatorname{tanaman}(15 \mathrm{ml} / \mathrm{tanaman}$ pada pemberian pertama, $25 \mathrm{ml} / \mathrm{tanaman}$ pada pemberian kedua dan $35 \mathrm{ml} /$ tanaman pada pemberian ketiga) dan pada sembilan petak percobaan diberikan ektrak daun kelor dengan dosis 150 $\mathrm{ml} / \mathrm{tanaman}(30 \mathrm{ml} / \mathrm{tanaman}$ pada pemberian pertama, $50 \mathrm{ml} / \mathrm{tanaman}$ pada pemberian kedua dan $70 \mathrm{ml} /$ tanaman pada pemberian ketiga).

g. Pemeliharaan

Pemeliharaan meliputi penyiraman, penyulaman, penyiangan serta pengendalian hama dan penyakit tanaman. Penyiraman dilakukan menggunakan gembor pada pagi dan sore hari. Penyulaman dilakukan pada saat tanaman berumur 2 HST. Penyulaman dilakukan dengan cara mengganti tanaman yang mati atau rusak dengan bibit cadangan yang telah disiapkan dan selama penelitian ada 11 tanaman yang rusak. Penyiangan terhadap gulma dilakukan dengan mencabutnya dan bila perlu dibantu dengan alat pencungkil. Hama yang menyerang tanaman sawi adalah ulat perusak daun (Plutella xylostella) dan ulat titik tumbuh (Crocidolomia binotalis). Pengendalian dilakukan dengan cara pengendalian secara fisik yaitu ditangkap dan dimatikan. h. Panen

Tanaman sawi putih dapat dipanen setelah tanaman berumur 35 HST, dilakukan dengan cara mencabut seluruh organ tanaman.

\subsection{Parameter Pengamatan}

a. Tinggi Tanaman $(\mathrm{cm})$

Tinggi tanaman diukur dari pangkal batang sampai ujung daun paling tinggi, pengukuran menggunakan pengaris. Pengukuran dilakukan pada semua tanaman saat berumur 11 HST, 18 HST, 25 HST, dan 32 HST

b. Jumlah Daun (helai)

Pengamatan terhadap jumlah daun dilakukan dengan cara menghitung semua daun yang terbentuk setiap tanaman. Pengukuran dilakukan pada saat tanaman berumur 11 HST, 18 HST, 25 HST, dan 32 HST.

c. Luas Daun $\left(\mathrm{cm}^{2}\right)$

Luas daun diukur pada saat akhir penelitian yakni 32 HST. Pengukuran luas daun dilakukan menggunakan metode citra dengan cara mengambil semua daun setiap tanaman, kemudiaan daun di potret menggunakan kamera digital. Luas area daun kemudian di hitung menggunakan program ImageJ versi 1. 410. $(\mathrm{cm})$

\section{d. Berat Segar Hasil (g)}

Penimbangan berat segar tanaman dilakukan pada semua organ lima tanaman setelah panen. Pengukuran dilakukan dengan cara memisahkan tanaman dari media tanam, kemudian batang dan akar dipotong selanjutnya ditimbang menggunakan timbangan analitik.

e. Berat Kering Hasil (g)

Pengukuran berat kering hasil dilakukan dengan cara menimbang semua organ tanaman selain berangkasan yang dikeringkan dengan cara penjemuran selama satu minggu. Penimbangan menggunakan timbangan analitik.

f. Panjang Akar $(\mathrm{cm})$

Panjang akar diukur dengan menggunakan penggaris pada setiap tanaman setelah akar dibersihkan. Akar diukur mulai dari leher hingga ujung akar. Pengukurannya dilakukan pada saat tanaman dipanen.

g. Berat Segar Berangkasan (g)

Berat segar berangkasan diukur dengan cara menimbang batang dan akar pada setiap tanaman setelah panen dengan menggunakan timbangan analitik.

h. Berat Kering Berangkasan (g)

Berat kering berangkasan diukur dengan cara menimbang batang dan akar setiap tanaman dengan timbangan analitik setelah dijemur selama satu minggu.

\section{i. Indeks Panen (\%)}

Indeks panen dihitung dengan cara membandingkan berat bagian tanaman yang bernilai ekonomis dengan berat seluruh bagian tanaman kemudian dikonversikan ke satuan \%. Indeks panen dihitung dengan rumus :

$$
\mathrm{IP}=\frac{\mathrm{BE}}{\mathrm{BE}+\mathrm{BNE}} \times 100 \%
$$

Keterangan

$$
\begin{array}{ll}
\mathrm{IP} & : \text { Indeks Panen } \% \\
\mathrm{BE} & : \text { Berat Segar Hasil (t/ha) } \\
\mathrm{BNE} & : \text { Berat Segar Berangkasan (t/ha) }
\end{array}
$$

\subsection{Analisis Data}

Data hasil pengamatan kemudian dianalisis dengan menggunakan sidik ragam (Anova) Rancangan Acak Kelompok (RAK). Rata-rata perlakuan selanjutnya diuji lanjut dengan menggunakan Duncan Multiple Range Test (DMRT) dengan tingkat signifikasi 5\% sesuai petunjuk Gomez dan Gomez (2010). Analisis data menggunakan program SAS 9.1.

\section{Hasil dan Pembahasan}

\subsection{Tinggi Tanaman}

Hasil sidik ragam (Anova) menunjukkan bahwa tidak terjadi pengaruh interaksi antara dosis pupuk Mitra Flora dan ekstrak daun kelor terhadap tinggi tanaman setiap waktu pengamatan, demikian juga pengaruh utama masing-

\begin{tabular}{|c|c|c|c|c|c|}
\hline \multirow{2}{*}{$\begin{array}{c}\text { Waktu } \\
\text { Pengamatan }\end{array}$} & \multirow{2}{*}{$\begin{array}{l}\text { Dosis Mitra } \\
\text { Flora }\end{array}$} & \multicolumn{3}{|c|}{ Dosis Ektrak Daun Kelor } & \multirow{2}{*}{ Rerata } \\
\hline & & Kontrol & $75 \mathrm{ml}$ & $150 \mathrm{ml}$ & \\
\hline \multirow{4}{*}{$11 \mathrm{HST}$} & Kontrol & $10,1 \mathrm{a}$ & $10,1 \mathrm{a}$ & $10,2 \mathrm{a}$ & $10,1 \mathrm{a}$ \\
\hline & $60 \mathrm{ml}$ & $10,7 \mathrm{a}$ & $10,4 \mathrm{a}$ & $10,3 \mathrm{a}$ & $10,5 \mathrm{a}$ \\
\hline & $120 \mathrm{ml}$ & $10,5 \mathrm{a}$ & $10,3 \mathrm{a}$ & $10,3 \mathrm{a}$ & $10,3 \mathrm{a}$ \\
\hline & Rerata & $10,4 \mathrm{a}$ & $10,3 \mathrm{a}$ & $10,2 \mathrm{a}$ & $(-)$ \\
\hline \multirow{4}{*}{$18 \mathrm{HST}$} & Kontrol & $17,5 \mathrm{a}$ & $19,4 \mathrm{a}$ & $17,3 \mathrm{a}$ & $18,1 \mathrm{a}$ \\
\hline & $60 \mathrm{ml}$ & $19,4 \mathrm{a}$ & $17,9 \mathrm{a}$ & $18,3 \mathrm{a}$ & $18,5 \mathrm{a}$ \\
\hline & $120 \mathrm{ml}$ & $17,4 \mathrm{a}$ & $19,1 \mathrm{a}$ & $18,9 \mathrm{a}$ & $18,5 \mathrm{a}$ \\
\hline & Rerata & $18,1 \mathrm{a}$ & $18,8 \mathrm{a}$ & $18,2 \mathrm{a}$ & $(-)$ \\
\hline \multirow{4}{*}{$25 \mathrm{HST}$} & Kontrol & $25,2 \mathrm{a}$ & $27,3 \mathrm{a}$ & $24,4 \mathrm{a}$ & $25,7 \mathrm{a}$ \\
\hline & $60 \mathrm{ml}$ & $28,8 \mathrm{a}$ & $26,8 \mathrm{a}$ & $27,9 \mathrm{a}$ & $27,8 \mathrm{a}$ \\
\hline & $120 \mathrm{ml}$ & $25,8 \mathrm{a}$ & $29,2 \mathrm{a}$ & $25,9 \mathrm{a}$ & $27,0 \mathrm{a}$ \\
\hline & Rerata & $26,6 \mathrm{a}$ & $27,8 \mathrm{a}$ & $26,1 \mathrm{a}$ & $(-)$ \\
\hline \multirow{4}{*}{32 HST } & Kontrol & $34,0 \mathrm{a}$ & $35,3 \mathrm{a}$ & $34,1 \mathrm{a}$ & $34,5 \mathrm{a}$ \\
\hline & $60 \mathrm{ml}$ & $38,8 \mathrm{a}$ & $34,9 \mathrm{a}$ & $37,4 \mathrm{a}$ & $37,0 \mathrm{a}$ \\
\hline & $120 \mathrm{ml}$ & $31,0 \mathrm{a}$ & $34,9 \mathrm{a}$ & $39,2 \mathrm{a}$ & $35,0 \mathrm{a}$ \\
\hline & Rerata & $34,6 \mathrm{a}$ & $35,0 \mathrm{a}$ & $36,9 \mathrm{a}$ & $(-)$ \\
\hline
\end{tabular}
masing faktor perlakuan baik dosis pupuk Mitra Flora maupun ekstrak daun kelor juga tidak terjadi terhadap tinggi tanaman.

Tabel 1. Tinggi Tanaman $(\mathrm{cm})$

Data Tabel 1. menunjukkan bahwa saat pengamatan 11 HST, tanaman sawi yang diberikan pupuk Mitra Flora dengan dosis $60 \mathrm{ml}$ per tanaman paling tinggi pada setiap waktu pengamatan sedangkan tanaman sawi yang tidak diberikan pupuk Mitra Flora selalu paling pendek. Tanaman sawi yang tidak diberikan ekstrak daun kelor paling tinggi tetapi saat pengamatan 18 HST dan 25 HST tanaman sawi yang diberikan ekstrak daun kelor dengan dosis $75 \mathrm{ml}$ per tanaman paling tinggi sedangkan pada saat pengamatan 32 HST tanaman sawi yang diberikan ekstrak daun kelor dengan dosis $150 \mathrm{ml}$ per tanaman menjadi paling tinggi.

\subsection{Jumlah Daun}

Hasil sidik ragam (Anova) menunjukkan bahwa tidak terjadi pengaruh interaksi antara pupuk Mitra Flora dan ekstrak daun kelor terhadap jumlah daun setiap waktu pengamatan, demikian juga pengaruh utama masing-masing faktor 
perlakuan baik dosis pupuk Mitra Flora maupun ekstrak daun kelor juga tidak terjadi terhadap jumlah daun.

Data Tabel 2. menunjukkan bahwa saat pengamatan 11 HST, 18 HST dan 32 HST tanaman sawi yang diberikan pupuk Mitra Flora dengan dosis $60 \mathrm{ml}$ per tanaman memiliki daun paling banyak, hanya pada pengamatan 25 HST tanaman sawi yang diberikan pupuk Mitra Flora dengan dosis $120 \mathrm{ml}$ per tanaman memiliki daun yang lebih banyak. Tanaman sawi yang diberikan ekstrak daun kelor dengan dosis $150 \mathrm{ml}$ per tanaman memiliki jumlah daun lebih banyak saat pengamatan 11 HST, tetapi saat pengamatan 18 HST daun tanaman sawi yang diberikan ekstrak daun kelor dengan dosis $75 \mathrm{ml}$ per tanaman lebih banyak dan selanjutnya saat pengamatan 25 HST daun tanaman sawi yang tidak diberikan ekstrak daun kelor dan daun tanaman sawi yang diberikan ekstrak daun kelor dengan dosis $150 \mathrm{ml}$ per tanaman lebih banyak. Pada pengamatan terakhir, daun tanaman sawi yang tidak diberikan ekstrak daun kelor paling banyak.

\begin{tabular}{|c|c|c|c|c|c|}
\hline \multirow{2}{*}{$\begin{array}{c}\text { Waktu } \\
\text { Pengamatan }\end{array}$} & \multirow{2}{*}{$\begin{array}{c}\text { Dosis Mitra } \\
\text { Flora }\end{array}$} & \multicolumn{3}{|c|}{ Dosis Ektrak Daun Kelor } & \multirow{2}{*}{ Rerata } \\
\hline & & Kontrol & $75 \mathrm{ml}$ & $150 \mathrm{ml}$ & \\
\hline \multirow{4}{*}{$11 \mathrm{HST}$} & Kontrol & $3,7 \mathrm{a}$ & $3,6 \mathrm{a}$ & $3,9 \mathrm{a}$ & $3,7 \mathrm{a}$ \\
\hline & $60 \mathrm{ml}$ & $3,9 \mathrm{a}$ & 3,7 a & $3,9 \mathrm{a}$ & $3,8 \mathrm{a}$ \\
\hline & $120 \mathrm{ml}$ & $3,7 \mathrm{a}$ & $3,6 \mathrm{a}$ & $3,9 \mathrm{a}$ & $3,7 \mathrm{a}$ \\
\hline & Rerata & $3,8 \mathrm{a}$ & $3,6 \mathrm{a}$ & $3,9 \mathrm{a}$ & $(-)$ \\
\hline \multirow{4}{*}{$18 \mathrm{HST}$} & Kontrol & $5,1 \mathrm{a}$ & $5,2 \mathrm{a}$ & $5,0 \mathrm{a}$ & $5,1 \mathrm{a}$ \\
\hline & $60 \mathrm{ml}$ & $5,4 \mathrm{a}$ & $5,4 \mathrm{a}$ & $5,0 \mathrm{a}$ & $5,3 \mathrm{a}$ \\
\hline & $120 \mathrm{ml}$ & $5,1 \mathrm{a}$ & $5,3 \mathrm{a}$ & $5,1 \mathrm{a}$ & $5,2 \mathrm{a}$ \\
\hline & Rerata & $5,2 \mathrm{a}$ & $5,3 \mathrm{a}$ & $5,0 \mathrm{a}$ & $(-)$ \\
\hline \multirow{4}{*}{$25 \mathrm{HST}$} & Kontrol & $6,6 \mathrm{a}$ & $6,6 \mathrm{a}$ & $6,7 \mathrm{a}$ & $6,6 \mathrm{a}$ \\
\hline & $60 \mathrm{ml}$ & $7,2 \mathrm{a}$ & $6,5 \mathrm{a}$ & $6,9 \mathrm{a}$ & $6,8 \mathrm{a}$ \\
\hline & $120 \mathrm{ml}$ & $6,8 \mathrm{a}$ & $7,4 \mathrm{a}$ & $7,1 \mathrm{a}$ & $7,1 \mathrm{a}$ \\
\hline & Rerata & $6,9 \mathrm{a}$ & $6,8 \mathrm{a}$ & $6,9 \mathrm{a}$ & $(-)$ \\
\hline \multirow{4}{*}{32 HST } & Kontrol & $10,3 \mathrm{a}$ & $8,7 \mathrm{a}$ & $10,7 \mathrm{a}$ & $9,9 \mathrm{a}$ \\
\hline & $60 \mathrm{ml}$ & $10,3 \mathrm{a}$ & $10,0 \mathrm{a}$ & $9,7 \mathrm{a}$ & $10,0 \mathrm{a}$ \\
\hline & $120 \mathrm{ml}$ & $9,7 \mathrm{a}$ & $11,3 \mathrm{a}$ & $8,7 \mathrm{a}$ & $9,9 \mathrm{a}$ \\
\hline & Rerata & $10,1 \mathrm{a}$ & $10,0 \mathrm{a}$ & $9,7 \mathrm{a}$ & $(-)$ \\
\hline
\end{tabular}

\subsection{Luas Daun}

Hasil sidik ragam (Anova) menunjukkan bahwa tidak terjadi pengaruh interaksi antara pupuk Mitra Flora dan ekstrak daun kelor terhadap luas daun, demikian juga pengaruh utama masing-masing faktor perlakuan baik dosis pupuk Mitra Flora maupun ekstrak daun kelor juga tidak terjadi terhadap luas daun.

Data Tabel 3. menunjukkan bahwa tanaman sawi yang diberikan pupuk Mitra Flora dengan dosis $120 \mathrm{ml}$ per tanaman memiliki permukaan daun yang cenderung lebih luas sedangkan tanaman sawi yang diberikan pupuk Mitra Flora dengan dosis $60 \mathrm{ml}$ per tanaman memiliki permukaan daun yang paling sempit. Sawi yang diberikan ekstrak daun kelor dengan dosis $75 \mathrm{ml}$ per tanaman memiliki permukaan daun yang cenderung lebih luas sedangkan tanaman sawi yang diberikan ekstrak daun kelor dengan dosis $150 \mathrm{ml}$ per tanaman memiliki permukaan daun yang paling sempit.

Tabel 3. Luas Daun $\left(\mathrm{cm}^{2}\right)$

\begin{tabular}{ccccc}
\hline \multirow{2}{*}{ Dosis Mitra Flora } & \multicolumn{3}{c}{ Dosis Ektrak Daun Kelor } & \multirow{2}{*}{ Rerata } \\
\cline { 2 - 4 } & Kontrol & $75 \mathrm{ml}$ & $150 \mathrm{ml}$ & \\
\hline Kontrol & $458,8 \mathrm{a}$ & $172,6 \mathrm{a}$ & $171,5 \mathrm{a}$ & $267,6 \mathrm{a}$ \\
$60 \mathrm{ml}$ & $180,2 \mathrm{a}$ & $349,3 \mathrm{a}$ & $155,6 \mathrm{a}$ & $228,4 \mathrm{a}$ \\
$120 \mathrm{ml}$ & $145,1 \mathrm{a}$ & $521,4 \mathrm{a}$ & $144,0 \mathrm{a}$ & $270,2 \mathrm{a}$ \\
\hline Rerata & $261,3 \mathrm{a}$ & $347,7 \mathrm{a}$ & $157,0 \mathrm{a}$ & $(-)$ \\
\hline Keterangan $:$ & Angka pada baris dan kolom yang diikuti dengan huruf yang sama tidak berbeda nyata \\
& menurut uji DMRT @ 5\%. (-) : Tidak terjadi interaksi antar faktor &
\end{tabular}

3.4 Berat Segar Hasil

Hasil sidik ragam (Anova) menunjukkan bahwa tidak terjadi pengaruh interaksi antara pupuk Mitra Flora dan ekstrak daun kelor terhadap berat segar hasil tanaman, demikian juga pengaruh utama masing-masing faktor perlakuan baik dosis pupuk Mitra Flora maupun ekstrak daun kelor juga tidak terjadi terhadap berat segar hasil.

Data Tabel 4. menunjukkan bahwa tanaman sawi yang diberikan pupuk Mitra Flora dengan dosis $60 \mathrm{ml}$ per tanaman memberikan hasil segar yang cenderung lebih berat sedangkan tanaman sawi yang tidak diberikan pupuk Mitra Flora memberikan hasil segar yang paling ringan. Sawi yang diberikan ekstrak daun kelor dengan dosis $150 \mathrm{ml}$ per tanaman memberikan hasil segar yang cenderung lebih berat sedangkan tanaman sawi yang diberikan ekstrak daun kelor dengan dosis $75 \mathrm{ml}$ per tanaman memberikan hasil segar yang paling ringan.

\begin{tabular}{ccccc} 
Tabel 4. Berat Segar Hasil $(\mathrm{g})$ & \multirow{3}{*}{ Rerata } \\
\cline { 2 - 4 } Dosis Mitra & \multicolumn{3}{c}{ Dosis Ektrak Daun Kelor } & \\
Flora & Kontrol & $75 \mathrm{ml}$ & $150 \mathrm{ml}$ & $127,6 \mathrm{a}$ \\
Kontrol & $139,9 \mathrm{a}$ & $116,0 \mathrm{a}$ & $127,0 \mathrm{a}$ & $149,1 \mathrm{a}$ \\
$60 \mathrm{ml}$ & $162,2 \mathrm{a}$ & $110,3 \mathrm{a}$ & $174,6 \mathrm{a}$ & $143,7 \mathrm{a}$ \\
$120 \mathrm{ml}$ & $126,5 \mathrm{a}$ & $147,5 \mathrm{a}$ & $157,3 \mathrm{a}$ & $(-)$ \\
\hline Rerata & $142,9 \mathrm{a}$ & $124,6 \mathrm{a}$ & $153,0 \mathrm{a}$ & $(-)$ \\
\hline Keterangan : & Angka pada baris dan kolom yang dikutit dengan huruf yang sama tidak berbeda nyata \\
& menurut uji DMRT @ 5\%. (-): Tidak terjadi interaksi antar faktor
\end{tabular}

\subsection{Berat Kering Hasil}

Hasil sidik ragam (Anova) menunjukkan bahwa tidak terjadi pengaruh interaksi antara pupuk Mitra Flora dan ekstrak daun kelor terhadap berat kering hasil tanaman, demikian juga pengaruh utama masing-masing faktor perlakuan baik dosis pupuk Mitra Flora maupun ekstrak daun kelor juga tidak terjadi terhadap berat kering hasil.

Tabel 5. Berat Kering Hasil (g)

\begin{tabular}{ccccc}
\hline Dosis Mitra & \multicolumn{3}{c}{ Dosis Ektrak Daun Kelor } & \multirow{2}{*}{ Rerata } \\
\cline { 2 - 4 } Flora & Kontrol & $75 \mathrm{ml}$ & $150 \mathrm{ml}$ & \\
\hline Kontrol & $12,4 \mathrm{a}$ & $13,0 \mathrm{a}$ & $12,4 \mathrm{a}$ & $12,6 \mathrm{a}$ \\
$60 \mathrm{ml}$ & $11,6 \mathrm{a}$ & $12,0 \mathrm{a}$ & $15,6 \mathrm{a}$ & $13,0 \mathrm{a}$ \\
$120 \mathrm{ml}$ & $13,5 \mathrm{a}$ & $14,3 \mathrm{a}$ & $13,4 \mathrm{a}$ & $13,8 \mathrm{a}$ \\
\hline Rerata & $12,5 \mathrm{a}$ & $13,1 \mathrm{a}$ & $13,8 \mathrm{a}$ & $(-)$ \\
\hline Keterangan : & Angka pada baris dan kolom yang diikuti dengan huruf yang sama tidak berbeda nyata \\
& menurut uji DMRT @ 5\%. (- ) : Tidak terjadi interaksi antar faktor &
\end{tabular}


Data Tabel 5. menunjukkan bahwa tanaman sawi yang diberikan pupuk Mitra Flora dengan dosis $120 \mathrm{ml}$ per tanaman memberikan hasil kering yang cenderung lebih berat sedangkan tanaman sawi yang tidak diberikan pupuk Mitra Flora memberikan hasil kering yang paling ringan. Sawi yang diberikan ekstrak daun kelor dengan dosis $150 \mathrm{ml}$ per tanaman memberikan hasil kering yang cenderung lebih berat sedangkan tanaman sawi yang tidak diberikan ekstrak daun kelor memberikan hasil kering yang paling ringan.

\subsection{Panjang Akar}

Hasil sidik ragam (Anova) menunjukkan bahwa tidak terjadi pengaruh interaksi antara pupuk Mitra Flora dan ekstrak daun kelor terhadap panjang akar, demikian juga pengaruh utama masing-masing faktor perlakuan baik dosis pupuk Mitra Flora maupun ekstrak daun kelor juga tidak terjadi terhadap panjang akar.

Data Tabel 6. menunjukkan bahwa tanaman sawi yang diberikan pupuk Mitra Flora dengan dosis $120 \mathrm{ml}$ per tanaman memiliki akar yang cenderung lebih panjang sedangkan tanaman sawi yang diberikan pupuk Mitra Flora dengan dosis $60 \mathrm{ml}$ per tanaman memiliki akar yang paling pendek. Sawi yang diberikan ekstrak daun kelor dengan dosis $150 \mathrm{ml}$ per tanaman memiliki akar yang cenderung lebih panjang sedangkan tanaman sawi yang diberikan ekstrak daun kelor dengan dosis $75 \mathrm{ml}$ per tanaman memiliki akar yang paling pendek.

Tabel 6. Panjang Akar (cm)

\begin{tabular}{ccccc}
\hline \multirow{2}{*}{ Dosis Mitra Flora } & \multicolumn{3}{c}{ Dosis Ektrak Daun Kelor } & \multirow{2}{*}{ Rerata } \\
\cline { 2 - 4 } & Kontrol & $75 \mathrm{ml}$ & $150 \mathrm{ml}$ & \\
\hline Kontrol & $17,5 \mathrm{a}$ & $18,5 \mathrm{a}$ & $22,9 \mathrm{a}$ & $19,6 \mathrm{a}$ \\
$60 \mathrm{ml}$ & $18,2 \mathrm{a}$ & $17,7 \mathrm{a}$ & $20,2 \mathrm{a}$ & $18,7 \mathrm{a}$ \\
$120 \mathrm{ml}$ & $24,1 \mathrm{a}$ & $20,6 \mathrm{a}$ & $17,6 \mathrm{a}$ & $20,8 \mathrm{a}$ \\
\hline Rerata & $19,9 \mathrm{a}$ & $18,9 \mathrm{a}$ & $20,2 \mathrm{a}$ & $(-)$ \\
\hline Keterangan : & Angka pada baris dan kolom yang diikuti dengan huruf yang sama tidak berbeda nyata \\
& menurut uji DMRT @ 5\%. (-) : Tidak terjadi interaksi antar faktor &
\end{tabular}

\subsection{Berat Segar Berangkasan}

Hasil sidik ragam (Anova) menunjukkan bahwa tidak terjadi pengaruh interaksi antara pupuk Mitra Flora dan ekstrak daun kelor terhadap berat segar berangkasan, demikian juga pengaruh utama masing-masing faktor perlakuan baik dosis pupuk Mitra Flora maupun ekstrak daun kelor juga tidak terjadi terhadap berat segar berangkasan.

Data Tabel 7. menunjukkan bahwa tanaman sawi yang diberikan pupuk Mitra Flora dengan dosis $60 \mathrm{ml}$ per tanaman memiliki berangkasan segar yang cenderung lebih berat sedangkan tanaman sawi yang tidak diberikan pupuk Mitra Flora memiliki berangkasan segar yang paling ringan. Sawi yang diberikan ekstrak daun kelor dengan dosis $150 \mathrm{ml}$ per tanaman memiliki berangkasan segar yang cenderung lebih berat sedangkan tanaman sawi yang tidak diberikan ekstrak daun kelor dan sawi yang diberikan ekstrak daun kelor dengan dosis $75 \mathrm{ml}$ per tanaman memiliki berangkasan segar yang paling ringan.

\begin{tabular}{|c|c|c|c|c|}
\hline \multirow{2}{*}{ Dosis Mitra Flora } & \multicolumn{3}{|c|}{ Dosis Ektrak Daun Kelor } & \multirow{2}{*}{ Rerata } \\
\hline & Kontrol & $75 \mathrm{ml}$ & $150 \mathrm{ml}$ & \\
\hline Kontrol & $10,3 \mathrm{a}$ & 9,9 a & $9,7 \mathrm{a}$ & $10,0 \mathrm{a}$ \\
\hline $60 \mathrm{ml}$ & $11,2 \mathrm{a}$ & $10,5 \mathrm{a}$ & $14,2 \mathrm{a}$ & $12,0 \mathrm{a}$ \\
\hline $120 \mathrm{ml}$ & $10,9 \mathrm{a}$ & $12,0 \mathrm{a}$ & $9,4 \mathrm{a}$ & $10,8 \mathrm{a}$ \\
\hline Rerata & $10,8 \mathrm{a}$ & $10,8 \mathrm{a}$ & $11,1 \mathrm{a}$ & $(-)$ \\
\hline
\end{tabular}

3.8 Berat Kering Berangkasan

Hasil sidik ragam (Anova) menunjukkan bahwa tidak terjadi pengaruh interaksi antara pupuk Mitra Flora dan ekstrak daun kelor terhadap berat kering berangkasan, demikian juga pengaruh utama masing-masing faktor perlakuan baik dosis pupuk Mitra Flora maupun ekstrak daun kelor juga tidak terjadi terhadap berat kering berangkasan.

Data Tabel 8. menunjukkan bahwa tanaman sawi yang tidak diberikan pupuk Mitra Flora memiliki berangkasan kering yang cenderung lebih berat sedangkan tanaman sawi yang diberikan pupuk Mitra Flora dengan dosis $60 \mathrm{~m}$ per tanaman memiliki berangkasan kering yang paling ringan. Sawi yang tidak diberikan ekstrak daun kelor dan sawi yang diberikan ekstrak daun kelor dengan dosis $75 \mathrm{ml}$ per tanaman memiliki berangkasan kering yang cenderung lebih berat sedangkan tanaman sawi yang diberikan ekstrak daun kelor dengan dosis $150 \mathrm{ml}$ per tanaman memiliki berangkasan kering yang paling ringan.

Tabel 8. Berat Kering Berangkasan (g)

\begin{tabular}{ccccc}
\hline \multirow{2}{*}{ Dosis Mitra Flora } & \multicolumn{3}{c}{ Dosis Ektrak Daun Kelor } & \multirow{2}{*}{ Rerata } \\
\cline { 2 - 4 } & Kontrol & $75 \mathrm{ml}$ & $150 \mathrm{ml}$ & \\
\hline Kontrol & $2,5 \mathrm{a}$ & $2,2 \mathrm{a}$ & $2,1 \mathrm{a}$ & $2,2 \mathrm{a}$ \\
$60 \mathrm{ml}$ & $1,8 \mathrm{a}$ & $1,8 \mathrm{a}$ & $2,1 \mathrm{a}$ & $1,9 \mathrm{a}$ \\
$120 \mathrm{ml}$ & $2,1 \mathrm{a}$ & $2,3 \mathrm{a}$ & $1,7 \mathrm{a}$ & $2,0 \mathrm{a}$ \\
\hline Rerata & $2,1 \mathrm{a}$ & $2,1 \mathrm{a}$ & $2,0 \mathrm{a}$ & $(-)$ \\
\hline Keterangan : & Angka pada baris dan kolom yang diikuti dengan huruf yang sama tidak berbeda nyata
\end{tabular}

3.9 Indeks Panen

Hasil sidik ragam (Anova) menunjukkan bahwa tidak terjadi pengaruh interaksi antara pupuk Mitra Flora dan ekstrak daun kelor terhadap indeks panen, demikian juga pengaruh utama masing-masing faktor perlakuan baik dosis pupuk Mitra Flora maupun ekstrak daun kelor juga tidak terjadi terhadap indek panen.

Tabel 9. Indeks Panen (\%)

\begin{tabular}{ccccc}
\hline \multirow{2}{*}{ Dosis Mitra Flora } & \multicolumn{3}{c}{ Dosis Ektrak Daun Kelor } & \multirow{2}{*}{ Rerata } \\
\cline { 2 - 4 } & Kontrol & $75 \mathrm{ml}$ & $150 \mathrm{ml}$ & \\
\hline Kontrol & $83,4 \mathrm{a}$ & $85,5 \mathrm{a}$ & $85,7 \mathrm{a}$ & $84,9 \mathrm{a}$ \\
$60 \mathrm{ml}$ & $86,4 \mathrm{a}$ & $86,9 \mathrm{a}$ & $88,1 \mathrm{a}$ & $87,2 \mathrm{a}$ \\
$120 \mathrm{ml}$ & $86,4 \mathrm{a}$ & $86,1 \mathrm{a}$ & $87,8 \mathrm{a}$ & $86,8 \mathrm{a}$ \\
\hline Rerata & $85,4 \mathrm{a}$ & $86,2 \mathrm{a}$ & $87,2 \mathrm{a}$ & $(-)$ \\
\hline Keterangan : & Angka pada baris dan kolom yang diikuti dengan huruf yang sama tidak berbeda nyata menurut \\
& uji DMRT @ 5\%. (-): Tidak terjadi interaksi antar faktor &
\end{tabular}

Data Tabel 9. menunjukkan bahwa tanaman sawi yang diberikan pupuk Mitra Flora dengan dosis $60 \mathrm{ml}$ per tanaman memiliki nilai indeks panen yang cenderung lebih tinggi sedangkan tanaman sawi yang tidak diberikan pupuk Mitra Flora memiliki indeks panen yang paling rendah. Sawi yang diberikan ekstrak daun kelor dengan dosis $150 \mathrm{ml}$ per tanaman memiliki nilai indeks panen yang cenderung lebih tinggi sedangkan tanaman sawi yang tidak diberikan ekstrak daun kelor memiliki indeks panen yang paling rendah.

3.10 Pembahasan
Pemberian pupuk Mitra Flora tidak memberikan pengaruh yang nyata pada pertumbuhan dan hasil tanaman sawi, walaupun demikian pemberian pupuk Mitra Flora dengan dosis $60 \mathrm{ml}$ per tanaman memberikan dampak berupa hasil tanaman yang paling berat dengan ukuran tanaman yang paling tinggi serta jumlah daun yang lebih banyak dengan berangkasan segar yang lebih berat dan nilai indeks panen yang lebih tinggi. Pemberian pupuk Mitra Flora dengan dosis yang lebih tinggi yakni $60 \mathrm{ml}$ per tanaman hanya memberikan permukaan daun yang lebih luas, akar yang lebih panjang serta bahan kering hasil yang lebih berat. 
Pemberian ekstrak daun kelor juga tidak berpengaruh secara signifikan terhadap pertumbuhan dan hasil tanaman sawi, tetapi pemberian dengan dosis tertinggi yakni $150 \mathrm{ml}$ per tanaman memberikan dampak berupa tanaman yang lebih tinggi, hasil segar dan bahan kering hasil yang lebih berat, akar yang lebih panjang, berangkasan segar yang lebih berat serta nilai indeks panen yang tinggi. Hal ini membuktikan bahwa dosis ekstrak daun kelor yang diterapkan terlalu rendah dan dimungkinkan diterapkan dosis yang lebih tinggi untuk meningkatkan pertumbuhan dan hasil tanaman sawi. Selain dosis, diduga bahwa konsentrasi ekstrak daun kelor yang digunakan dalam penelitian ini masih terlalu rendah.

\section{Simpulan}

Dari analisis hasil dan pembahasan yang dilakukan maka dapat disimpulkan beberapa hal sebagai berikut:

a. Tidak terjadi pengaruh interaksi antara pupuk Mitra Flora dan ekstrak daun kelor terhadap semua parameter yang diamati, demikian juga pengaruh utama masing-masing faktor perlakuan baik dosis pupuk Mitra Flora maupun ekstrak daun kelor juga tidak terjadi terhadap semua parameter yang diamati.

b. Dosis pupuk Mitra Flora $60 \mathrm{ml}$ per tanaman merupakan dosis yang optimum yang memberikan hasil sawi seberat $149,1 \mathrm{~g}$ per tanaman.

c. Dosis ektrak daun kelor $150 \mathrm{ml}$ per tanaman memberikan hasil sawi terbaik seberat $153 \mathrm{~g}$ per tanaman.

\section{Pustaka}

Abdalla, M. M. 2013. The potential of Moringa oleifera extract as a biostimulant in enhancing the growth, biochemical and hormonal contents in rocket (Eruca vesicaria subsp. sativa) plants. academicJounals. 5(3):4249.

Anonim. 1995. Penggunaan Zat Pengatur Tumbuh. Buletin Teknik Sukarami. No 1(3-5). Balai Penelitian Tanaman Pangan. Sukarami. Jawa Barat.
BPS TTU. 2007. Timor Tengah Utara Dalam Angka. BPS TTU. Kefamenanu. Culver M, Fanuel T dan Chiteka A Z. 2012. Effect of Moringa Extract on Growth and Yield of Tomato. Greener Journal of Agricultural Sciences. 2(5):207-211

Danusastro. 1989. Zat Pengatur Tumbuh. Gramedia. Jakarta.

Fuglie L J. 2000. New Uses of Moringa Studied in Nicaragua: ECHO's Technical Network Site-networking global hunger solutions. ECHO, Nicaragua.

Gomez K A dan Gomez A A. 1995. Prosedur Statistik untuk Penelitian Pertanian. Edisi ke 2. Jakarta: UI Press.

Haryanto. E., Suhartini. T., Rahayu. E dan Sunarjono. H. H. 2008. Sawi dan selada. Penebar swadaya. Jakarta.

Intan R. D. A. 2008. Peranan dan Fungsi Fitohormon bagi Pertumbuhan Tanaman. Makalah. Fakultas Pertanian Universitas Padjadjaran Bandung.

Kusumo. 1984. Zat Pengatur Tumbuh. Yasaguna. Jakarta.

Lingga P. dan Marsono. 2008. Petunjuk Penggunaan Pupuk. Penebar Swadaya. Bogor.

Novizan. 2005. Petunjuk Pemupukan yang Efektif. Agro Media Pustaka. Jakarta Nusifera dan Sosiawan. 2001. Respons Tanaman Sawi (Brassica juncea L.) Terhadap Pupuk Daun Nutra-Phos N Dengan Konsentrasi Bervariasi. [online] diakses pada tanggal 25 April 2015.

Prabhu M, Kumar A R, Rajamani K. 2010. Influence of different organic substances on growth and herb yield of sacred basil (Ocimum sanctum L) Ind. J. Agric. Res. 44(1):48-52.

Prosecus P. 2006. Biosynthesis-Plant Hormones and Growth Regulators: Chemistry and Biology. Biosynth Ag. Co., Switzerland.

Rukmana R. 1994. Bertanam Sawi dan Pitsai. Kanisius Jakarta.

Sunu, P. 1999. Pengaruh Aplikasi Zat Pengatur Tumbuh CPPU terhadap "Fruit Set" pada Tanaman Jambu Mete (Anacardium occidentale L.). Penelitian Bidang Pertanian FP UNS. Surakarta 